\title{
The Effect of Smartphone Overdependence on Friend Relationship for Community Care and Social Intervention; Focused on Elementary School Students
}

\author{
Mi-Ran Lee ${ }^{1}$ \\ ${ }^{1}$ Professor, Department of Social Welfare, Kosin University, Korea, dsmr0815@naver.com
}

\begin{abstract}
In today's situation where all activities are conducted non-face-to-face for a long time caused by COVID-19, there is a need to manage the dysfunctional phenomenon of smartphones in various ways and develop creative solutions for the next generation students who require care and intervention in terms of community health management and socio-emotional health prevention. Therefore, by examining how aggression and impulsivity caused by smartphone overdependence affects friend relationships, and searching for ways to improve the coping ability and relationship with smartphone addiction, this study is intended to provide basic data necessary to promote the holistic growth of students. The subjects of this study were elementary school students attending elementary schools and community children's centers in Busan from November 18 to 22, 2020, and face-to-face surveys and indepth interviews were conducted. As a result of the study, it was found that the overdependence of elementary school students on smartphones was higher in the case of single children and double-income parents, and the higher overdependence of the smartphone, the higher the aggression and impulsivity, and aggression and impulsivity were correlated with negative friend relationship, the higher the smartphone overdependence score was, the higher the negative friend relationship was. Based on this study, in non-face-to-face education sites and various intervention sites of the local community in the era of Corona, it is very necessary to educate the smartphone control ability and to develop a new deliberation system of YouTube, and differentiated education and active parental intervention are required by grade level.
\end{abstract}

Keywords: COVID-19, Smartphone, Social Welfare Intervention Plan, YouTube Deliberation, Holistic Growth

\section{Introduction}

As COVID-19 continues, the corona blue phenomenon, which means depression and lethargy due to social distancing and non-face-to-face, is increasing. In particular, COVID-19 deepens the psychological problems experienced by the vulnerable and underprivileged. Academic and relationship-building issues that are important to youth in need of care and attention require intervention and support.

As it is rapidly changing into the non-face-to-face untect era caused by Corona Blue, demand and utilization of smartphones is increasingly exploding in the global society. The use of smartphones is becoming more and more common and universal so that the appearance of being indulged in smart phones regardless of time and place, and age or gender, has become a daily landscape[1]. Due to these various factors, not only the demand for smartphones is increasing, but also the technology of the smartphone itself, which is more highly utilized in the consumption market, is also advancing.

Received: December 27, 2020; $1^{\text {st }}$ Review Result: February 7, 2021; $2^{\text {nd }}$ Review Result: March 29, 2021 Accepted: April 30, 2021 
A smart phone is a highly functional mobile phone that can freely install and use various mobile apps according to the needs of users, and an enhanced intelligent terminal equipped with computer support functions such as Internet communication and information search[2].

Due to the convenience and entertainment advantages of smartphones, immature adolescents can lead to smartphone overdependence, and smartphone overdependence can be expressed as various dysfunctional problems, which are mainly addiction phenomenon by overdependence of smartphones [3].

According to the 2016 smartphone and internet overdependence survey results report by the Ministry of Science, ICT and Future Planning and the National Information Society Agency (2017), 17.8\% (7,426 thousand people) of smartphone users aged 3 to 99 are reported as a high risk group for smartphone addiction and a potential risk group for smartphone addiction[4]. As such, the number of smartphone addiction group is increasing year by year, and it is surveyed with $30.6 \%$ of adolescents $(649,000)$, $17.9 \%$ of children $(591,000), 16.1 \%$ of adults $(4,826,000)$, and $11.7 \%$ of $60 \mathrm{~s}(360,000$, new survey) and the smartphone addiction rate of adolescents was the highest, followed by infants.

As smartphone overdependence is increasing mainly in minors such as children and adolescents, it is a matter of care and intervention that needs urgent approach in the local community. Furthermore, smartphone addiction of children and adolescents can lead to mental problems such as aggression, impulsivity, depression, and isolation. In addition, smartphone addiction may deteriorate family or friend relationships by misadaptation to reality, and may appear as psychological and social pathologies, such as having difficulty maintaining normal daily life or schoolwork.

Therefore, it is an important reality that requires care and intervention in terms of health management and socio-emotional health prevention of the local community, in particular, in today's situation where all studies are conducted for a long time as non-face-to-face classes due to corona, the need to manage the dysfunctional phenomenon of smartphones in various ways and to develop creative solutions is urgent.

Therefore, by examining how aggression and impulsivity caused by smartphone overdependence affects friend relationships, focusing on elementary school students, and searching for ways to cope with smartphone addiction and to improve friend relationship, this study has important significance in preparing the basic data necessary to promote the holistic growth of students.

\section{Study method}

This study is aimed to examined the effect of smartphone overdependence on friend relationship focusing on aggression and impulsivity, for elementary school students attending elementary schools located in Busan.

\subsection{Subjects}

The subjects of this study were elementary school students attending at 3 elementary schools in Busan, E elementary school, G elementary school, and J elementary school, and elementary school students attending at 1 local children's center in Busan. Face-to-face surveys and in-depth interviews were conducted on 18 to 22 of November 2020.

\subsection{Data Gathering Procedure \& Ethical Considerations}

After explaining the purpose of the study and how to fill out the questionnaire, a self-written face-toface questionnaire survey was conducted to students who agreed to the study, and a questionnaire survey and in-depth interviews were conducted through additional explanations by each question item 
considering elementary school students. For the ethical consideration of the subject, we guided the purpose of the study through a survey guide in the preface during the survey, made only those who agreed with their free will voluntarily participate in the questionnaire, and informed that they can stop at any time if they do not want to participate. The questionnaire was distributed 20 copies to A local children's center located in D-gu, Busan, 10 copies to the elementary school of $\mathrm{H}$ church in B-gu, and 80 copies to total 3 elementary schools of E elementary school, G elementary school, J elementary school. A total of 110 copies were distributed and 102 questionnaires were collected. For in-depth interview, 10 subjects were surveyed at A local children's center in D-gu, Busan.

\subsection{Research Instrument \& Data Analysis}

Data analysis used a questionnaire method and an interview method using a structured questionnaire to conduct face-to-face surveys and in-depth interviews for elementary school students. The collected data were analyzed using SPSS after editing and encoding. In-depth interviews data were analyzed through open coding, axis coding, and selective coding by applying the grounded theory method suggested by Strauss and Corbin (2001).

1) Smartphone overdependence scale

The smartphone overdependence scale used in this study used the smartphone addiction selfdiagnosis scale for adolescents developed by the National Information Society Agency (2016). This scale consists of a total of 10 questions with three sub-factors of control failure, salience, and problematic consequence and is a 4-point Likert scale per question, and is classified into high risk user group, potential risk user group, general user group

2) Aggression scale

Aggression scale as a tool used to measure the degree of aggression, a test tool modified from BussDukee Hostility Inventory (BDHI) by Buss \& Dukee (1957) for children and adolescents was used. The scale question is a 4-point Likert scale, and the higher the score, the higher the aggressive tendency is interpreted.

3) Impulsivity scale (Barratt Impulsivity Scale; BIS-11)[5]

BIS-11 was developed by Barratt (1959) to measure impulsivity. This scale consists of a total of 23 questions including 6 questions of cognitive impulsivity, 8 questions of exercise impulsivity, and 9 questions of unplanned, which is 4-point Likert scale.

4) Friend relationship scale

To measure friend relationship, only the friend relationship part was used in the social relationship scale developed by Turner et al. (1983). It consists of a total of 20 questions: 7 questions on positive friend relationship and 13 questions on negative friend relationship. The measurement question is a 5point Likert scale, and it can be inferred that the higher the score, the smoother the friend relationship, and the lower the score, the more lonely tends to be.

5) In-depth interview

Interview questionnaire was developed through literature review and study meeting, and it starts with open and broad questions, and the questions are structured in a form that includes detailed questions about the process leading to aggression, impulsivity, and friend relationship depending on the degree of smartphone use.

\section{Study Results}

\subsection{General Characteristics}

The general characteristics of the 102 survey subjects in this study, that is, gender, presence of siblings 
or siblings, the presence of double-income at parents' workplace, average daily usage time of smartphone, user group by smartphone overdependence scale, smartphone main use activities (multiple responses, 179 items) are shown in Table 1 below.

In terms of gender, there were 61 male students $(59.8 \%), 41$ female students $(40.2 \%)$, and in terms of grade, there were 4 students in first grade(3.9\%), 9 students in second grade (8.8\%), 14 students in third grade (13.7\%), 24 students in fourth grade (23.5\%), 28 students in fifth grade (27.5\%), and 23 students in sixth grade (22.5\%). In the presence or absence of brothers or sisters, the most respondents were 'Yes (brothers, sisters, siblings)' with 86 people (84.3\%), and in the presence or absence of double-income at the parents' workplace, 'double-income' with 61 people (59.8\%) were the most, and in the average daily smartphone usage time ' 3 hours' with 23 people $(22.5 \%)$ showed the most responses, and as a result of the user group by smartphone overdependence scale, "potential risk user group" with 53 people (52.0\%) were the most, and as for smartphone main activities (179 multiple responses), 'YouTube' with 63 people (35.2\%) and 'Games' with 63 people (35.2\%) showed the same number of responses.

[Table 1] General Characteristics of Study Subjects

\begin{tabular}{|c|c|c|c|}
\hline Item & Division & $\mathrm{n}$ & $\%$ \\
\hline \multirow{2}{*}{ Gender } & Male & 61 & $59.8 \%$ \\
\hline & Female & 41 & $40.2 \%$ \\
\hline \multirow{6}{*}{ Grade } & 1 grade & 4 & $3.9 \%$ \\
\hline & 2 grade & 9 & $8.8 \%$ \\
\hline & 3 grade & 14 & $13.7 \%$ \\
\hline & 4 grade & 24 & $23.5 \%$ \\
\hline & 5 grade & 28 & $27.5 \%$ \\
\hline & 6 grade & 23 & $22.5 \%$ \\
\hline \multirow[b]{2}{*}{ Having brothers or sisters } & No(single) & 16 & $15.7 \%$ \\
\hline & $\begin{array}{c}\text { Yes } \\
\text { (Brother, sister, sibling) }\end{array}$ & 86 & $84.3 \%$ \\
\hline \multirow{2}{*}{$\begin{array}{l}\text { Parent workplace } \\
\text { Double-income }\end{array}$} & Double-income & 61 & $59.8 \%$ \\
\hline & $\begin{array}{c}\text { Not Double-income } \\
\text { (One-income, Unemployed) }\end{array}$ & 41 & $40.2 \%$ \\
\hline \multirow{13}{*}{$\begin{array}{l}\text { Smartphone daily average } \\
\text { Hours of use }\end{array}$} & 0.5 hour & 7 & $6.9 \%$ \\
\hline & 1 hour & 16 & $15.7 \%$ \\
\hline & 1.5 hour & 1 & $1.0 \%$ \\
\hline & 2 hour & 18 & $17.6 \%$ \\
\hline & 3 hour & 23 & $22.5 \%$ \\
\hline & 4 hour & 8 & $7.8 \%$ \\
\hline & 5 hour & 16 & $15.7 \%$ \\
\hline & 6 hour & 3 & $2.9 \%$ \\
\hline & 7 hour & 2 & $2.0 \%$ \\
\hline & 8 hour & 3 & $2.9 \%$ \\
\hline & 9 hour & 1 & $1.0 \%$ \\
\hline & 10 hour & 2 & $2.0 \%$ \\
\hline & 12 hour & 2 & $2.0 \%$ \\
\hline \multirow{2}{*}{$\begin{array}{l}\text { Smartphone overdependence } \\
\text { user group by scale }\end{array}$} & General user group & 39 & $38.2 \%$ \\
\hline & Potential Risk User Group & 53 & $52.0 \%$ \\
\hline
\end{tabular}




\begin{tabular}{|c|c|c|c|}
\hline & High risk user group & 10 & $9.8 \%$ \\
\hline \multirow{3}{*}{$\begin{array}{c}\text { Smartphone main activity } \\
\text { (179 multiple responses) }\end{array}$} & SNS & 34 & $19.0 \%$ \\
\cline { 2 - 4 } & YouTube & 63 & $35.2 \%$ \\
\cline { 2 - 4 } & Game & 63 & $35.2 \%$ \\
\cline { 2 - 4 } & etc & 19 & $10.6 \%$ \\
\hline
\end{tabular}

[Table 2] Factor Analysis by Category

\begin{tabular}{|c|c|c|c|}
\hline Category & & ivision & Frequency (average score, number of people) \\
\hline \multirow{6}{*}{$\begin{array}{c}\text { Smartphone } \\
\text { overdependence }\end{array}$} & \multirow{3}{*}{ By factor } & Control Failure & 2.8 points \\
\hline & & Salience & 2.6 points \\
\hline & & Problematic Consequence & 1.7 points \\
\hline & \multirow{3}{*}{ Result Analysis } & $\begin{array}{l}\text { General user group } \\
(10 \sim 22 \text { points })\end{array}$ & $39(38.2 \%)$ \\
\hline & & $\begin{array}{l}\text { Potential risk user group } \\
\text { (23 } 30 \text { points })\end{array}$ & $53(52.0 \%)$ \\
\hline & & $\begin{array}{l}\text { High risk user group } \\
\text { (31 40 points) }\end{array}$ & $10(9.8 \%)$ \\
\hline \multirow{7}{*}{ Aggression } & \multirow{4}{*}{ By factor } & Physical aggression & 1.3 points \\
\hline & & Verbal aggression & 1.3 points \\
\hline & & Direct aggression & 1.8 points \\
\hline & & Indirect aggression & 1.9 points \\
\hline & \multirow{3}{*}{ Result Analysis } & $\begin{array}{c}\text { Normal } \\
(7 \sim 15 \text { points })\end{array}$ & $81(79.4 \%)$ \\
\hline & & $\begin{array}{c}\text { High } \\
\text { (16 20 points) }\end{array}$ & $17(16.7 \%)$ \\
\hline & & $\begin{array}{c}\text { Very high } \\
(21 \sim 28 \text { points })\end{array}$ & $4(3.9 \%)$ \\
\hline \multirow{6}{*}{ Impulsivity } & \multirow{3}{*}{ By factor } & Cognitive impulsivity & 2.2 points \\
\hline & & Exercise impulsivity & 2.1 points \\
\hline & & Cognitive impulsivity & 2.4 points \\
\hline & \multirow{3}{*}{ Result Analysis } & $\begin{array}{c}\text { Normal } \\
\text { (7 15 points) }\end{array}$ & $44(43.1 \%)$ \\
\hline & & $\begin{array}{c}\text { High } \\
\text { (16 20 points) }\end{array}$ & $46(45.1 \%)$ \\
\hline & & $\begin{array}{c}\text { Very high } \\
(21 \sim 28 \text { points })\end{array}$ & $12(11.8 \%)$ \\
\hline \multirow{3}{*}{$\begin{array}{l}\text { Negative } \\
\text { Friend } \\
\text { relationship }\end{array}$} & \multirow{3}{*}{ Result Analysis } & $\begin{array}{c}\text { Normal } \\
(7 \sim 15 \text { points })\end{array}$ & $79(77.5 \%)$ \\
\hline & & $\begin{array}{c}\text { High } \\
\text { (16 20 points) }\end{array}$ & $17(16.7 \%)$ \\
\hline & & $\begin{array}{c}\text { Very high } \\
\text { (21 28 points) }\end{array}$ & $6(5.9 \%)$ \\
\hline
\end{tabular}

In the analysis result by factor in the smartphone overdependence scale, 'control failure' was the highest by 2.8 points, for 53 people (52.0\%) in the 'potential risk user group', and in the analysis result by factor in the aggressiveness scale, 'indirect aggression' was the highest by 1.9 points , and 'normal' was the most by 81 (79.4\%), and in the analysis result by factors in the impulsivity scale, 'unplanned impulsivity' was the highest by 2.4 points and 'high' was the most by $46(45.1 \%)$, and in the negative friend relationship scale, 'normal' was the most by 79 (77.5\%). 


\subsection{Survey Results}

When comparing the average scores of male and female in smartphone overdependence, aggression, impulsivity, and negative friend relationship, smartphone overdependence of both male and female students was the same by 2.3 points, and aggression of male students was higher by 1.7 points, and impulsivity of male students was higher by 2.3 points, and negative friend relationship of female students was higher by 1.9 points.

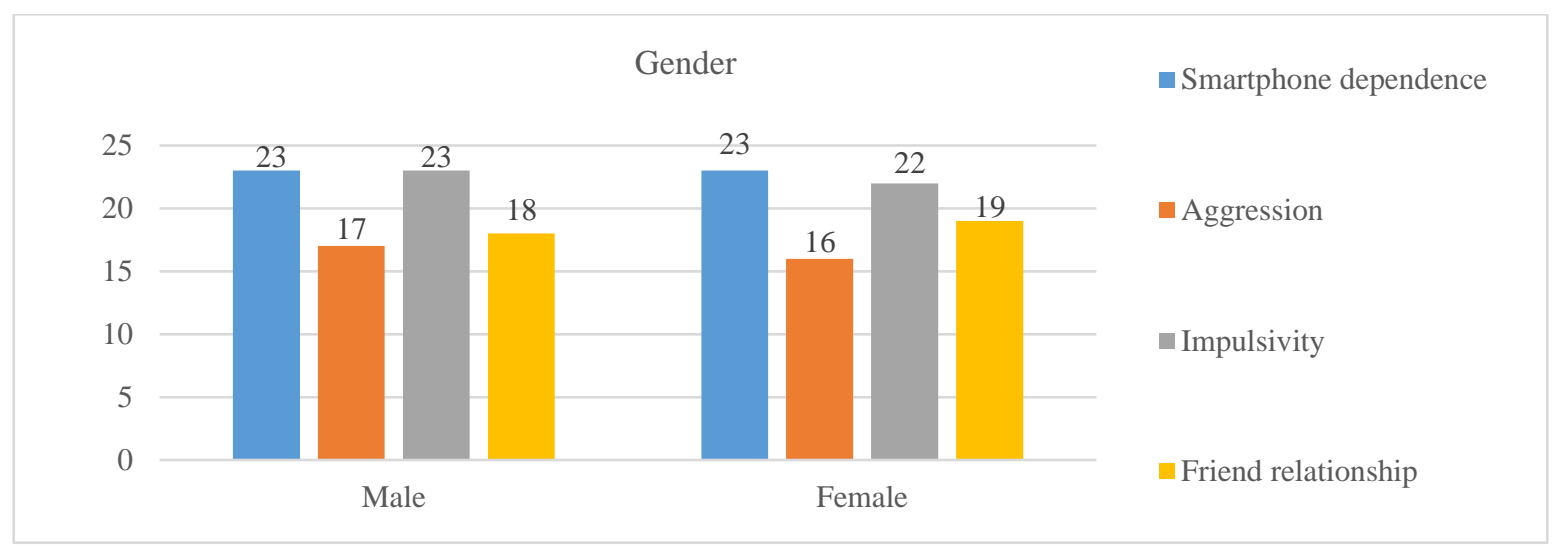

[Fig. 1]Smartphone Overdependence, Aggression, Impulsivity, Negative Friend Relationship by Gender

When comparing the average score of smartphone overdependence, aggression, impulsivity, and negative friend relationship by grade, smartphone overdependence was the highest in 2nd and 3rd grades, by 2.6 points for 2nd and 3rd grade, and was the second in the 6th grade, by 2.5 points for 6th grade. Aggression was the highest by 1.9 points in $2 \mathrm{nd}, 3 \mathrm{rd}$ and 6 th grade. Impulsivity was the highest in 3rd grade, by 2.6 points for 3rd grade, by 2.5 points for 2 nd grade, by 2.4 points for 6 th grade. Negative friend relationship was the highest in 3rd grade, by 2.3 points for 3rd grade, by 2.1 points for 2nd grade, by 1.9 points for 1 st grade.

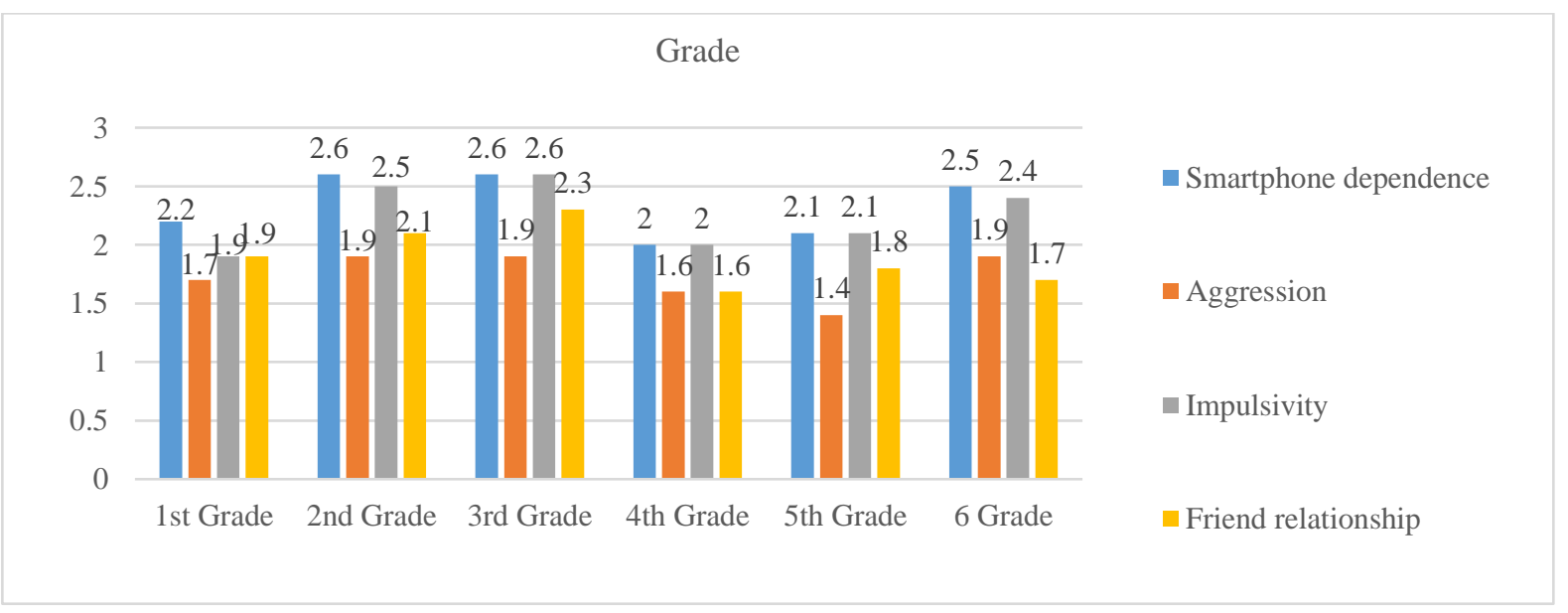

[Fig. 2] Smartphone Overdependence, Aggression, Impulsivity, and Negative Friend Relationship by Grade

When comparing the average score of smartphone overdependence, aggression, impulsivity, and negative friend relationship by presence of siblings or not, smartphone overdependence was the highest by 2.6 points, aggression 2 points, impulsivity 2.5 points, and negative friend relationship 2.1 points when there is no sibling. 


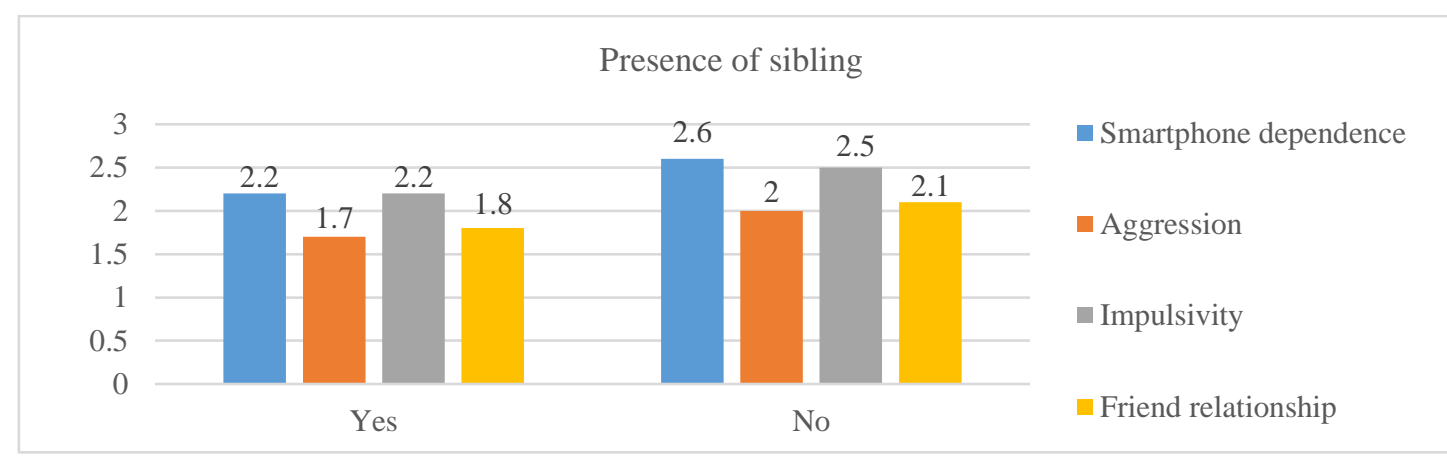

[Fig. 3] Smartphone Overdependence, Aggression, Impulsivity, and Negative Friend Relationship by the Presence of Siblings or Not

When comparing the average score of smartphone overdependence, aggression, impulsivity, and negative friend relationship by parent double-income or not, smartphone overdependence, aggression, and negative friend relationship were was highest in the case of parent double-income, by 2.4 points for smartphone overdependence, by 1.8 points for aggression, by 1.9 points for negative friend relationship; and impulsivity was higher by 2.3 points in no double-income items by 0.1 points than in double-income item.

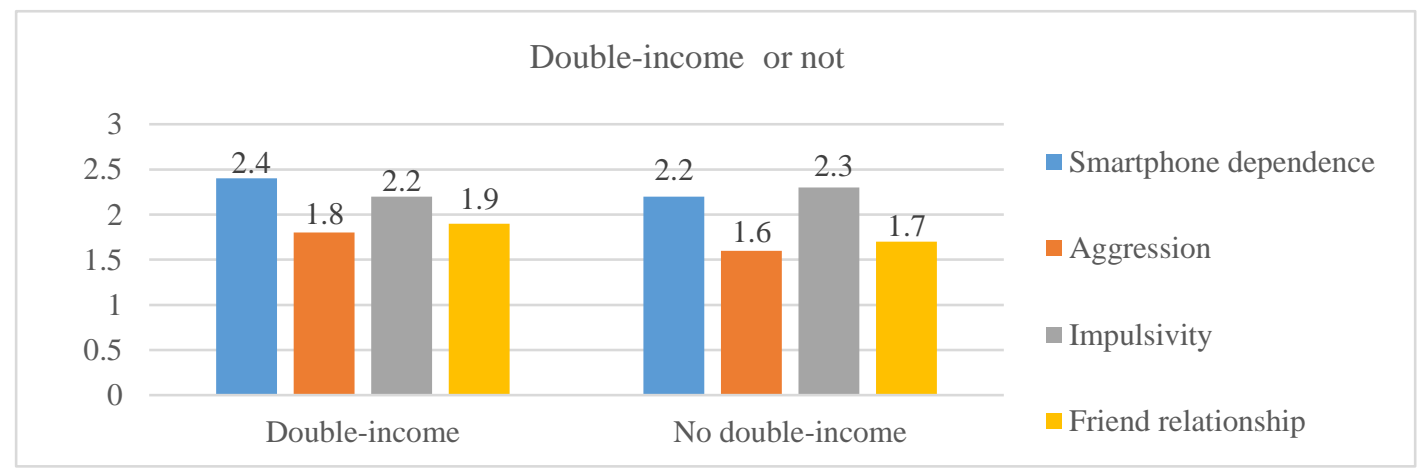

[Fig. 4] Smartphone Overdependence, Aggression, Impulsivity, Negative Friend Relationship by Parent Double-income or Not

When comparing the average score of smartphone overdependence, aggression, impulsivity, and negative friend relationship by smartphone main use activity, smartphone overdependence was highest by 2.5 points, aggression by 1.9 points, impulsivity by 2.4 points, and negative friend relationship by 1.9 points in the case of game activity.

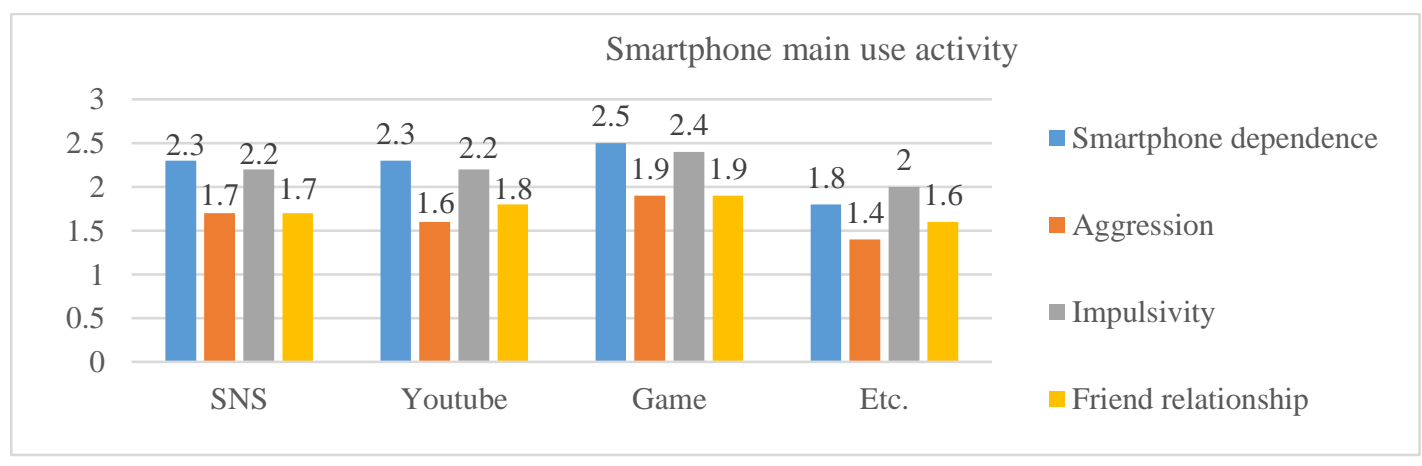

[Fig. 5] Smartphone Overdependence, Aggression, Impulsivity, Negative Friend Relationship by Smartphone Main Use Activity 
When comparing the average daily usage time of a smartphone and the average score of smartphone overdependence, aggression, impulsivity, and negative friend relationship by smartphone overdependence user group, the higher the use time, the higher the average score for smartphone overdependence, and the higher the risk group, the higher the aggression, impulsivity, and negative friend relationship.

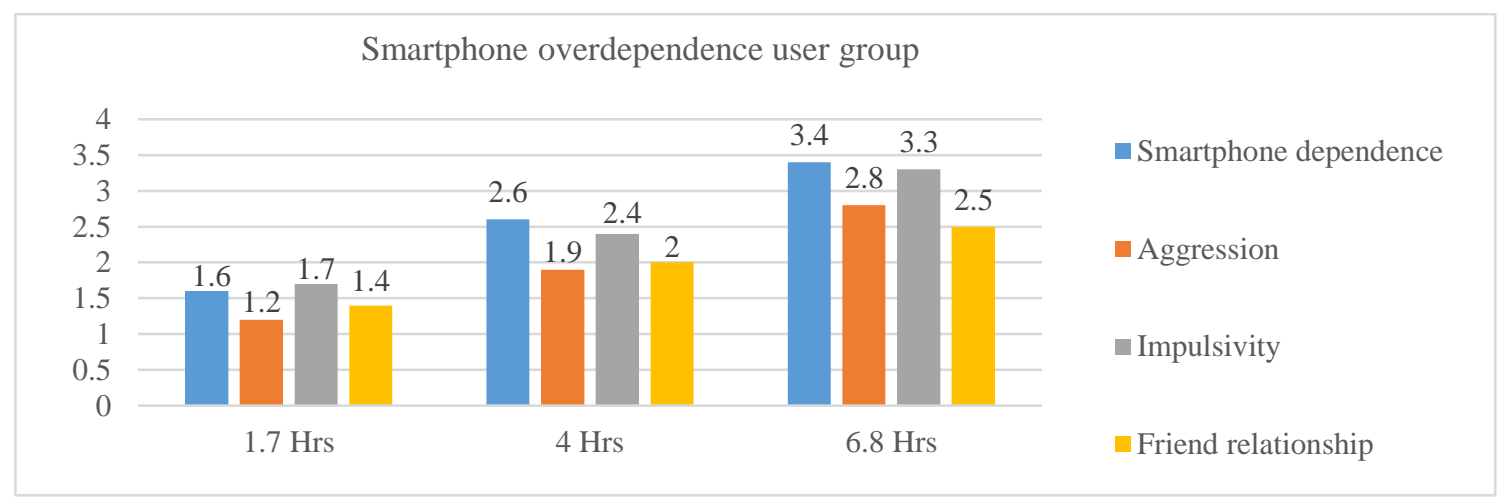

[Fig. 6] Smartphone Usage Time and Overdependence, Aggression, Impulsivity, Negative Friend Relationship by Smartphone Overdependence User Group

As a result of the correlation analysis between variables in this study, it was found that there is a correlation between the variables of smartphone overdependence, aggression and impulsivity, and negative friend relationship. In this study, the first hypothesis, 'The elementary school students' smartphones overdependence will be higher for boys than for girls', was rejected because both boys and girls showed the same 2.3 points of smartphone overdependence.

[Table 3] Correlation between Variables

\begin{tabular}{|c|c|c|c|c|c|}
\hline & & $\begin{array}{c}\text { Average } \\
\text { overdependen } \\
\text { ce }\end{array}$ & $\begin{array}{l}\text { Average } \\
\text { negative } \\
\text { friend } \\
\text { relationship }\end{array}$ & $\begin{array}{c}\text { Average } \\
\text { aggression }\end{array}$ & Average Impulsivity \\
\hline \multirow{3}{*}{$\begin{array}{l}\text { Average smartphone } \\
\text { overdependence }\end{array}$} & $\begin{array}{c}\text { Pearson } \\
\text { Correlation } \\
\text { coefficient }\end{array}$ & 1 & .629 & .827 & .745 \\
\hline & $\begin{array}{c}\text { Significance } \\
\text { probability (both } \\
\text { sides) }\end{array}$ & & .000 & .000 & .000 \\
\hline & $\mathrm{N}$ & 102 & 102 & 102 & 102 \\
\hline \multirow{3}{*}{$\begin{array}{l}\text { Average negative } \\
\text { friend relationship }\end{array}$} & $\begin{array}{l}\text { Pearson } \\
\text { Correlation } \\
\text { coefficient }\end{array}$ & & 1 & .532 & .455 \\
\hline & $\begin{array}{c}\text { Significance } \\
\text { probability (both } \\
\text { sides) }\end{array}$ & & & .000 & .000 \\
\hline & $\mathrm{N}$ & & & 102 & 102 \\
\hline \multirow{3}{*}{ Average aggression } & $\begin{array}{l}\text { Pearson } \\
\text { Correlation } \\
\text { coefficient }\end{array}$ & & & 1 & .656 \\
\hline & $\begin{array}{c}\text { Significance } \\
\text { probability (both } \\
\text { sides) }\end{array}$ & & & & .000 \\
\hline & $\mathrm{N}$ & & & 102 & 102 \\
\hline
\end{tabular}


In the second hypothesis, 'The only child will have a higher smartphone overdependence in elementary school students', the average score for smartphone overdependence was 2.6 points for the only child, and 2.2 points for the case of siblings. so it was adopted because the overdependence score of the only child was higher. In the third hypothesis, 'Smartphone overdependence of elementary school students will be higher if parents are double-income", the average score for smartphone overdependence was 2.4 points for double-income, and 2.2 points for no double-income, so it was adopted because the overdependence score of double-income was higher. In the fourth hypothesis, 'The higher the overdependence of an elementary school student's smartphone, the higher the aggression and impulsivity will be.' the higher the average score of smartphone overdependence was, the higher the aggression and impulsivity was, so it was adopted. The fifth hypothesis, "Aggression and impulsivity will be correlated with negative friend relationship", was adopted because there was a correlation as a result of the correlation analysis between aggression and impulsivity and negative friend relationship. In the sixth hypothesis,'The higher the elementary school student's overdependence on smartphones will affect the negative friend relationship', the higher the average score for smartphone overdependence, the higher negative friend relationships was, so it was adopted.

[Table 4] Characteristics of Qualitative Study Participants

\begin{tabular}{|c|c|c|c|c|c|c|}
\hline \multicolumn{2}{|c|}{ Division } & Gender & Grade & Brothers & Smartphone use & Double-income or not \\
\hline \multirow{4}{*}{$\begin{array}{l}\text { General user } \\
\text { group }\end{array}$} & Participant 1 & Female & 4grade & $\mathrm{X}$ & 2 hours & $\mathrm{X}$ \\
\hline & Participant 2 & Female & 2grade & $\mathrm{O}$ & 2 hours & $\mathrm{X}$ \\
\hline & Participant 3 & Female & 2grade & $\mathrm{O}$ & 2 hours & $\mathrm{O}$ \\
\hline & Participant 4 & Female & 3 grade & $\mathrm{O}$ & 1 hour & $\mathrm{O}$ \\
\hline \multirow{2}{*}{$\begin{array}{l}\text { Potential risk } \\
\text { user group }\end{array}$} & Participant 5 & Female & 6grade & $\mathrm{X}$ & 3 hours & $X$ \\
\hline & Participant 6 & Male & 6grade & $\mathrm{X}$ & 4 hours & $\mathrm{X}$ \\
\hline \multirow{4}{*}{$\begin{array}{l}\text { High risk user } \\
\text { group }\end{array}$} & Participant 7 & Male & 6grade & $\mathrm{X}$ & 6 hours & $\mathrm{X}$ \\
\hline & Participant 8 & Female & 6grade & $X$ & 7 hours & $X$ \\
\hline & Participant 9 & Male & 4grade & $\mathrm{X}$ & 5 hours & $\mathrm{O}$ \\
\hline & Participant 10 & Male & 5grade & $\mathrm{O}$ & 5 hours & $\mathrm{O}$ \\
\hline
\end{tabular}

The in-depth interview was conducted by the researcher and the participant in 1:1 face to face manner, and according to the purpose of this study, and it was conducted based on a questionnaire designed to enable an in-depth search of elementary school students' smartphone overdependence, aggression, impulsivity, and friend relationship. The in-depth interview was conducted by one researcher, and the interview time took about 30 minutes to 1 hour. After the in-depth interview, in case the meaning was unclear or in case there were any questions, additional information was collected by visiting the local children's center. 
[Table 5] Concept and Category of Friend Relationship through Aggression and Impulsivity by Smartphone Overdependence

\begin{tabular}{|c|c|c|c|c|}
\hline Paradigm & Key word & Upper category & Lower category & Conceptualization \\
\hline $\begin{array}{l}\text { Causal } \\
\text { condition }\end{array}$ & $\begin{array}{l}\text { Self } \\
\text { control }\end{array}$ & $\begin{array}{l}\text { Smartphone use } \\
\text { time varies } \\
\text { depending on } \\
\text { smartphone self- } \\
\text { control ability }\end{array}$ & $\begin{array}{l}\text { Insufficience of control } \\
\text { ability }\end{array}$ & $\begin{array}{c}\text { Unconscious smartphone overuse } \\
\text { Poor smartphone use control ability } \\
\text { Despite being aware of overuse of smartphones, } \\
\text { not feeling the need to reduce smartphone use time } \\
\text { Often stay up all night }\end{array}$ \\
\hline \multirow{2}{*}{$\begin{array}{l}\text { Contextua } \\
1 \\
\text { condition }\end{array}$} & \multirow{2}{*}{$\begin{array}{l}\text { Lack of } \\
\text { cognition }\end{array}$} & \multirow{2}{*}{$\begin{array}{l}\text { Cognitive } \\
\text { condition causing } \\
\text { smartphone } \\
\text { overdependence }\end{array}$} & $\begin{array}{l}\text { Lack of self-awareness } \\
\text { of overuse of } \\
\text { smartphones }\end{array}$ & $\begin{array}{l}\text { Despite awareness of overuse of smartphones, } \\
\text { Difficulty reducing usage time } \\
\text { Low overdependence recognition of smartphones, } \\
\text { leading to overuse }\end{array}$ \\
\hline & & & $\begin{array}{l}\text { High smartphone } \\
\text { acceptance by peer } \\
\text { groups }\end{array}$ & $\begin{array}{c}\text { Thinking of smartphones as a means of play within } \\
\text { peer groups } \\
\text { A culture in which smartphone } \\
\text { overuse/overdependence is insignificant and } \\
\text { understood }\end{array}$ \\
\hline \multirow[b]{2}{*}{$\begin{array}{l}\text { Central } \\
\text { phenome } \\
\text { non }\end{array}$} & \multirow[b]{2}{*}{$\begin{array}{l}\text { Negativeef } \\
\text { fect }\end{array}$} & $\begin{array}{l}\text { Adverse effect on } \\
\text { the body }\end{array}$ & $\begin{array}{l}\text { Health problems by } \\
\text { failure to adjust } \\
\text { smartphone use time }\end{array}$ & $\begin{array}{l}\text { lack of sleeping time } \\
\text { Deteriorated eyesight }\end{array}$ \\
\hline & & $\begin{array}{l}\text { Emotional and } \\
\text { psychological } \\
\text { changes }\end{array}$ & $\begin{array}{l}\text { Formation of } \\
\text { Depression }\end{array}$ & $\begin{array}{l}\text { Anxiety formed depending on the degree of } \\
\text { dependence on smartphones } \\
\text { Anxiety due to restrict of smartphone by a third } \\
\text { party } \\
\text { Depression formed depending on the degree of } \\
\text { dependence on smartphones } \\
\text { Not using smartphone makes something interesting } \\
\text { disappear and feel depressed }\end{array}$ \\
\hline \multirow{2}{*}{$\begin{array}{l}\text { Interventi } \\
\text { onal } \\
\text { condition }\end{array}$} & \multirow[t]{2}{*}{$\begin{array}{l}\text { Negative } \\
\text { factor }\end{array}$} & $\begin{array}{l}\text { Harm of } \\
\text { smartphone }\end{array}$ & $\begin{array}{l}\text { Hearing swear words } \\
\text { from a third party }\end{array}$ & $\begin{array}{c}\text { experience of hearing swear words with a } \\
\text { smartphone } \\
\text { A lot of swear words in sns, } \\
\text { Frequent swear words }\end{array}$ \\
\hline & & $\begin{array}{l}\text { Easy accessibility } \\
\text { of paid payment }\end{array}$ & $\begin{array}{l}\text { Impulsive cash } \\
\text { payment }\end{array}$ & $\begin{array}{l}\text { Impulsive cash payment } \\
\text { Payment made without parental consent }\end{array}$ \\
\hline \multirow{4}{*}{$\begin{array}{l}\text { Action/ } \\
\text { Interactio } \\
\mathrm{n}\end{array}$} & \multirow{4}{*}{$\begin{array}{l}\text { Express } \\
\text { anger }\end{array}$} & \multirow{2}{*}{$\begin{array}{l}\text { Reckless use of } \\
\text { slang }\end{array}$} & Use of swear words & $\begin{array}{l}\text { Using swear words to friends } \\
\text { Using voice chat to swear a lot }\end{array}$ \\
\hline & & & $\begin{array}{l}\text { Internet buzzword } \\
\text { use }\end{array}$ & $\begin{array}{l}\text { Using bad internet buzzwords } \\
\text { No reluctance to use bad Internet buzzwords }\end{array}$ \\
\hline & & \multirow{2}{*}{$\begin{array}{l}\text { Excessive } \\
\text { immersion in } \\
\text { smartphone } \\
\text { games }\end{array}$} & Aggression & $\begin{array}{l}\text { Revenge as a group in the game } \\
\text { Feeling angry and resentful about the events in the } \\
\text { game }\end{array}$ \\
\hline & & & $\begin{array}{l}\text { Blur between reality } \\
\text { and games }\end{array}$ & $\begin{array}{l}\text { Like in-game friends more than real friends } \\
\text { Excessive dependence on in-game friends }\end{array}$ \\
\hline
\end{tabular}




\begin{tabular}{|c|c|c|c|c|}
\hline \multirow{3}{*}{ Result } & \multirow{3}{*}{$\begin{array}{l}\text { Negative } \\
\text { friend } \\
\text { relationshi } \\
\quad p\end{array}$} & \multirow{3}{*}{$\begin{array}{l}\text { Adverse effect on } \\
\text { friend } \\
\text { relationship }\end{array}$} & $\begin{array}{l}\text { Disconnection of } \\
\text { communication }\end{array}$ & $\begin{array}{l}\text { Not following the trend makes communication with } \\
\text { friends be cut off. } \\
\text { Failing to adapt to the trend leads friend relationship } \\
\text { to be difficult }\end{array}$ \\
\hline & & & $\begin{array}{l}\text { Occurrence of } \\
\text { Communication } \\
\text { problem }\end{array}$ & $\begin{array}{l}\text { Problems with communication with friends while } \\
\text { doing other things with a smartphone } \\
\text { Misunderstanding occurs in communicating with } \\
\text { friends when not using a smartphone }\end{array}$ \\
\hline & & & $\begin{array}{l}\text { Formation of } \\
\text { alienation }\end{array}$ & $\begin{array}{l}\text { Failing to adapt to the trend creates a sense of } \\
\text { alienation } \\
\text { Low adaptation to trend creates a sense of alienation }\end{array}$ \\
\hline
\end{tabular}

In this study, data were analyzed through open coding, axis coding, and selective coding by applying the grounded theory method suggested by Strauss and Corbin (2001)[6]. First, open coding was conducted to convert the contents of individual in-depth interviews into verbatim records, and disassemble the original data, read them carefully, find specific phenomena (concepts) and give them names. At this stage, concepts similarly or meaningfully grouped were categorized and attempted to identify specific processes hidden in the data.

To find out how elementary school students' overdependence on smartphones affects their friend relationship through aggression and impulsivity, open coding was performed to extract interview contents of research participants into semantic units and categorize them into similar characteristics. As a result of analyzing the collected data, a total of 6 key words, a total of 9 upper categories, 16 lower categories, and 32 conceptualizations were derived. The results are shown in [Table 5].

In the grounded theory method, after open coding, axis coding was conducted to identify various causal conditions, actions/interactions, and connection processes leading to results among categories, and contextual conditions and interventional conditions that affect these processes, and thus the theory to understand the phenomenon should be presented[7]. In this study, axis coding was performed based on the model, and the final model in [Figure 7] was derived.

\begin{tabular}{|c|c|c|c|}
\hline & \multicolumn{2}{|c|}{$\begin{array}{c}\text { Causal condition } \\
<\text { Self-control }> \\
\text { Smartphone use time varies depending on } \\
\text { smartphone self-control ability }\end{array}$} & \\
\hline $\begin{array}{l}\text { Contextual condition } \\
<\text { Lack of recognition }> \\
\text { Cognitive conditions to induce } \\
\text { overdependence on smartphones }\end{array}$ & \multicolumn{2}{|c|}{$\begin{array}{l}\text { Central phenomenon } \\
<\text { Negative effect }> \\
\text { Adverse effects on the body } \\
\text { Emotional and psychological changes }\end{array}$} & $\begin{array}{c}\text { Interventional condition } \\
<\text { Negative factor }> \\
\text { The harm of the smartphone } \\
\text { Easy accessibility of paid payment }\end{array}$ \\
\hline \multicolumn{2}{|c|}{$\begin{array}{c}\text { Action/interaction } \\
<\text { Express anger }> \\
\text { Reckless use of slang } \\
\text { Excessive immersion in smartphone games }\end{array}$} & \multicolumn{2}{|c|}{$\begin{array}{c}\text { Result } \\
<\text { Negative friend relationship }> \\
\text { Adverse effect on friend relationship }\end{array}$} \\
\hline
\end{tabular}

[Fig. 7] Paradigm Model for 'the Effect of Smartphone Overdependence on Friend Relationship through Aggression and Impulsivity' 


\section{Conclusion and Discussion}

This study examines how aggression and impulsivity caused by over-dependence on smartphones affects friendship. Furthermore, it is intended to provide basic data necessary to promote the holistic growth of students by seeking ways to improve coping skills and relationships with smartphone addiction. The subjects of this study were elementary school students attending elementary schools and community children's centers from November 18 to 22, 2020, and face-to-face surveys and in-depth interviews were conducted. As a result of the study, it was found that the overdependence of elementary school students on smartphones was higher in the case of single children and double-income parents, and the higher overdependence of the smartphone, the higher the aggression and impulsivity. Also, aggression and impulsivity were correlated with negative friend relationship, the higher the smartphone overdependence score was, the higher the negative friend relationship was. Based on this study, in nonface-to-face education sites and various intervention sites of the local community in the era of Corona virus, it is very necessary to educate the smartphone control ability and to develop a new deliberation system of YouTube, and differentiated education and active parental intervention are required by grade level.

In conclusion, based on the results of the study, seeking the holistic growth of students as members of the community, the theoretical and practical implications for social welfare intervention are as follows.

First, it is necessary to provide customized education for elementary school students' smartphone control skills by each stage. Looking at this study, as the result of each factor of the smartphone overdependence scale, 'regulation failure' was the highest score by 2.8 points. In qualitative study, the causal condition leading to smartphone overdependence was 'the smartphone use time varies depending on the smartphone control ability', and the sub-factors were 'insufficience of control ability' and 'lack of control ability'. Accordingly, it can be seen that if the smartphone control ability of elementary school students is insufficient or lacking, the phone is overused, and the more smartphone is used, the more the smartphone is overdependent. Of course, they can get useful information through smartphone and have positive functions such as communicating with friends[8]. We are well aware of the problems that appear due to overdependence of smartphones, but due to lack of ability to control the use of smartphones or failure of control, they overuse smartphones and over-depend on smartphones. Therefore, it is necessary for elementary school students to use smartphones 'appropriately' so that problems due to overdependence do not occur.

When training to prevent addiction to smartphones (or computers) in elementary school, it focuses not only on the negative results of addiction, but on 'the ability to control'. It is important for elementary school students to recognize that the problems by smartphone overdependence do not occur if accompanied by adequate rest. focusing on the need for adequate rest when using a smartphone.

Second, the new deliberation system development for YouTube is very urgent. Currently, the deliberation for YouTube is conducted through artificial intelligence of YouTube itself. YouTube has the advantage that everyone can upload videos freely and enjoy videos easily, but if the uploader (hereinafter referred to as YouTuber) does not set an age limit, they can easily view stimulating or obscene contents without age restrictions even 19 limit contents. Therefore, it is very necessary to develop a new deliberation system for YouTube. Here deliberation refers to deliberation that is conducted through artificial intelligence of YouTube itself, and is evaluated by a person or institution afterwards[9]. Using artificial intelligence of YouTube, 'keyword' is generated for each video uploaded, and artificial intelligence of YouTube first filters out harmful contents to elementary school students through the keyword, and then harmful contents not filtered out by the artificial intelligence are passed after being deliberated by a person or institution.

Also, in the case of the "review' video shown in the qualitative study, "age limit" must be applied 
unconditionally when uploading a review of a game judged by 19 limit so that under 19 years of age cannot view it. YouTubers must open a new clause that states that they unconditionally set an age limit when uploading a review video of 19 limit game, so that age restrictions can be set by force.

Third, development of active hobbies other than smartphones and active intervention of parents are needed. As a result of this study, the smartphone overdependence score was 2.4 when there were doubleincome parents, and the smartphone overdependence score was 2.6 when there were no siblings, and the overdependence scores were higher than when there were single-income/unemployed parents and siblings. Therefore, practical efforts are required to divide when parents are at home and when they are not.

In particular, it is necessary to develop and support hobbies that help prevent elementary school students' smartphone overdependence through sound hobbies and help develop emotions as well as sense of achievement. Therefore, it should be recognized by elementary school students that playing with parents is more fun than smartphones. Also, it's wise to give praise and rewards if they use smartphone properly.

Fourth, detailed and differentiated smartphone use guidance education by each grade is required. As a result of this study, the smartphone overdependence score was higher in the lower grades, and the smartphone overdependence score decreased in the 4th and 5th grades, and reached higher in the 6th grade. Therefore, in the case of the lower grades of elementary school students, we should lower their eye level and develop the instructional education separately as a lecture that the lower grades will enjoy. In the case of 6th grade elementary school students, a higher level of education is required than the lower grades as their vocabulary rises and self-development increases compared with lower grades. Also, as the ego develops, it may have a repulsion against the smartphone instructional education[10]. Therefore, it is necessary to naturally reduce the smartphones overdependence phenomenon through programs that search for things more interesting and focusable than smartphones rather than compulsive education.

Finally, the generalization is limited due to the large difference in the number of respondents by each grade because the questionnaire survey was conducted mainly in the higher grades due to the characteristics of elementary school students who have difficulty understanding questions in the case of lower grades. Also, this study did not focus on the positive functions and roles of smartphones.

\section{References}

[1] D. I. Kim, Y. J. Chung, Y. H. lee, B. K. Kim. H. J. Jeon,, Develpment and Validation of Youth Smartphone Addiction Self-report Scale, Korea Journal of Counseling, (2016), Vol.17, No.3, pp.319-335, DOI : 10.15703/kjc.17.3.201606.319

[2] S. C. Shin, H. W. Song, The Moderating Effect of Self-esteem on the Relationship between the Smartphone Overuse, Aggression and Impulsiveness of Elementary School Students, The Korean Journal Child Education, (2019), Vol.28, No.4, pp.231-245, DOI : 10.17643/KJCE.2019.28.4.13

[3] M. R. Lee, A Study on Ambivalent Characteristics on the Consume Behavior Satisfaction of Korean University Students based on Smartphone User Observation, International Journal of Engineering \& Technology, (2019), Vol.8, No.1-4, pp.518-526.

[4] S. Y. Kim, Understanding Activity Participation in Children with Physical Disabilities in Korea, International Journal of Child Welfare Promotion and Management, (2020), Vol.4, No.1, pp.7-14.

[5] S. R. Lee, W, H. Lee, J. S. Park, S. M. Kim, J. W. Kim, J. H. Shim, The Study on Reliability and Validity of Korean Version of the Barratt Impulsiveness Scale-11-Revised in Nonclinical Adult Subject, Journal of Korean Neuropsychiatric Association, (2012), Vol.51, No.6, pp.378-386, https://doi.org/10.4306/jknpa.2012.51.6.378

[6] M. R. Lee, Exploratory Research on Local Care Services for Resource Sharing and Local Care Services System, Asia 
The Effect of Smartphone Overdependence on Friend Relationship for Community Care and Social Intervention; Focused on Elementary School Students

Life Sciences, (2019), Vol.19, No.2, pp.83-95.

[7] D. M. Kim, C. H. Lee, Phenomenological Approach of Overindulgence Smartphones Experience in Elementary Student, Journal of Korean Practical Arts Education, (2015), Vol.28, No.2, pp.65-90, UCI : G704000635.2015.28.2.011

[8] S. Y. Lee, M. J. Chung, Forest School Character Education Program for Elementary School Children: Development and Efficacy, International Journal of Child Warfare Promotion and Management, (2017), Vol.1, No.1, pp.71-76.

[9] S. J. Kang, H.Y. Kwon, Meta-Analysis of the Variables related to Subjective Well-being of Youth, International Journal of Child Welfare Promotion and Management, (2020), Vol.4, No.1, pp.23-28, DOI:10.21742/IJCWPM.2020.4.1.04

[10] S. D. Park, E. J. Kim, K. C. Kim, A Meta Analysis on Robot Learning in early childhood Education in Korea, International Journal of Computer Science and Information Technology for Education, (2016), Vol.1, No.1, pp.41-46. 